\title{
Municipal engineers and local government in the Transvaal before 1910
}

\author{
HARRI MÄKI
}

\begin{abstract}
:
This paper examines the history of the first town engineers in the Transvaal before the Union. It will briefly examine the changes in local government in the Transvaal, focusing on municipal engineers. Examination is made of the selection processes applied in their appointments and the circumstances at the end of their tenures. It explores what was expected of municipal engineers during this period; shows what their position within the municipal structure was; and explains how vague their job description was in relation to their wide field of operation. The development of the engineer's position in the municipal management hierarchy is interesting. He was an important figure in local government, had specific responsibilities and enjoyed specific powers. It emerges that most early town engineers had training via apprenticeship for the positions they held and that there was added pressure from elected councillors in municipalities who were prone to assiduously monitor how officials were spending public money.
\end{abstract}

Keywords: Municipal history, civil engineering, water supply, sanitation, Transvaal, Benoni, Boksburg, Germiston, Heidelberg, Johannesburg, Klerksdorp, Krugersdorp, Pietersburg, Potchefstroom, Pretoria, Standerton, Volksrust

Disciplines: History, Engineering, Public Management

\section{Introduction}

The development of municipal engineering in South Africa started slowly in the late $19^{\text {th }}$ century. The first municipal engineers were appointed in the 1850s in Cape Town, Grahamstown and Port Elizabeth in the Cape Colony, and in Pietermaritzburg in Natal. However, all the initial municipal engineers, with the exception of that of Cape Town, were temporary appointments. Only after diamond mining operations started at Kimberley in the 1870s and gold mining on the Witwatersrand in the 1880s, did the situation change. The formation of large human settlements in the new industrial centres of Southern Africa forced the colonial governments of the Cape and Natal to contemplate creating permanent posts for engineers in the local government sector. In the 1880s Durban, Kimberley and Johannesburg appointed their first permanent municipal engineers.

- Dr Harri Mäki of Finland is an associate researcher of the CuDyWat research group in the School of Basic Sciences at the Vaal Triangle Faculty of the North-West University. E-mail: harri66maki@gmail.com. 
Our present knowledge on these early municipal engineers is limited. Hardly any detailed work has been done on their activities in the formative years of South Africa's urban areas. What is evident is that the early engineers often had to bear the brunt of public frustration - frequently for urban problems not necessarily related to the provision of proper municipal services.

It also seems as if these early municipal engineers hardly ever reaped the benefits of the experience of their counterparts in Britain, even if the obstacles were similar. Rapid urbanisation called for strong local measures to ensure a safe and comfortable urban environment, but the people moving in from the rural areas hardly attached much importance to the need for proper sanitary measures. It was the municipal engineer who had to quietly cope with public objections to the improvements necessary to create a sound, well-organised and healthy urban community. The engineer could seldom rely on support or protection from elected councils. Councillors were almost obsessive about saving the ratepayers from 'unnecessary expenses' on basic municipal infrastructure. Local government, in itself a veritable minefield of local, colonial and republican political sentiments, was often beset with difficulties, rapid development in Africa, far away from the commercial and manufacturing centres of Europe and North America.

Finding qualified engineers was initially far from easy; there were few resident in South Africa. This situation changed rapidly after the discovery of diamonds at Kimberley. Engineers from all over the world were lured to South Africa and later their numbers increased even more when extensive gold deposits were found on the Witwatersrand in 1886. Few of them were keen to settle in as municipal engineers as long as the mining industry, as the major private sector operation in the region, required innovative engineers. Locally the prospects for training engineers were slim. The training of the first mining engineers in South Africa started modestly in 1894 in Cape Town and Kimberley, but the first degrees in engineering in South Africa were only conferred in 1918. Most of the engineering needs had to be met by engineers from Europe, especially the United Kingdom. Most of the early engineers from the United Kingdom were trained via the apprenticeship system, because there was no formal training as such in municipal engineering. Even if an engineer held a university degree it was usually in mathematics or another related field. ${ }^{1}$

In this article the focus will be on the first town engineers in the former Transvaal Colony before the establishment of the Union of South Africa in 1910. Under consideration are all the municipalities having a town engineer before $1910 .^{2}$ What were the criteria when the municipalities appointed new town engineers? How did the level of previous work experience (in the fields of water supply and sanitation, for instance) influence the selection of a town engineer? An investigation will also be made into how and why these municipal officials ended their tenures. The twelve case municipalities can be divided in two groups, namely mining towns connected to the Rand Water Board, and others. The first group comprises Johannesburg, Germiston, Boksburg, Benoni and Krugersdorp. The other seven municipalities (Pretoria, Klerksdorp, Potchefstroom, Heidelberg, Standerton, Pietersburg and Volksrust) form the second group. Examination will also be made of any significant differences between these two groups.

The field of municipal engineering only gained public recognition after breakthroughs in the understanding of disease transmission and improved public health measures during the second half of the $19^{\text {th }}$ century. The first formal professional institution for municipal engineers in England was established in 1873 and the first professional examinations for municipal engineers were offered in 1877.

2 For a more detailed examination of Johannesburg and Pretoria, see H. Mäki and J. Haarhoff, 'Municipal engineers in Johannesburg and Pretoria before 1910'. TD: The Journal for Transdisciplinary Research in Southern Africa, 5, 2, 2009, 230-247. 


\section{Municipal developments in the Transvaal}

Before the Anglo-Boer War (1899-1902), there were experimental attempts to establish municipal government in the Zuid-Afrikaanse Republiek in the urban centres of Potchefstroom, Pretoria, Lichtenburg, Lydenburg, Rustenburg, Zeerust and Johannesburg. Of these only Johannesburg was successful. It seems that in all the other cases the municipalities failed due to a lack of financial viability. Municipal government was introduced permanently in this area only under British control after the Anglo-Boer War. ${ }^{3}$ The municipalities of Boksburg, Heidelberg, Klerksdorp, Krugersdorp, Middelburg, Pietersburg, Standerton, Potchefstroom and Germiston were formally established in 1903. The municipality of Barberton was created in January 1904. A number of Urban District Boards were also created in 1903. They were granted municipal status later in 1904, but were called minor municipalities, whereas the aforementioned ten plus Johannesburg and Pretoria were called major municipalities. Roodepoort-Maraisburg became a major municipality in 1905 and Benoni was separated from Boksburg and proclaimed a major municipality in 1907. Of the major municipalities Middelburg, Barberton and Roodepoort-Maraisburg did not appoint a municipal engineer before 1910; among the minor municipalities the only appointment of a municipal engineer before 1910 was at Volksrust. ${ }^{4}$

Contemplated from the perspective of demography it becomes evident that the 11 municipalities appointing municipal engineers before 1905 were among the 13 largest municipalities. (See Table 1.) The population of the whole Transvaal in 1904 was almost 1,3 million people. An estimated 83\% of the Transvaal's urban residents had the benefit of a municipal engineer. By 1910 this percentage had increased to $89 \%$.

Table 1. Most populous municipalities in the Transvaal in 1904 and 1910

\begin{tabular}{|c|c|c|}
\hline & Population in $1904^{5}$ & $\begin{array}{c}\text { Population in } \\
1910^{6}\end{array}$ \\
\hline Johannesburg & 160,000 & 210,000 \\
\hline Pretoria & 35,000 & 41,600 \\
\hline Germiston & 29,127 & 54,000 \\
\hline Krugersdorp & 19,483 & 44,500 \\
\hline Boksburg & 14,650 & 40,000 \\
\hline Benoni & (part of Boksburg) & 21,000 \\
\hline Potchefstroom & 9,086 & 14,037 \\
\hline Springs & 6,500 & 4,900 \\
\hline Standerton & 5,208 & 3,000 \\
\hline Roodepoort & $4,000^{8}$ & 35,000 \\
\hline
\end{tabular}

L.P. Green, History of Local Government in South Africa: An Introduction (Cape Town: Juta \& Co., 1957), 44-76.

H.T.M. Bell and C.A. Lane (eds.), A Guide to the Transvaal (Johannesburg, 1905), 97; W.P.M. Henderson and F.G. Pay (eds.), Official South African Municipal Year Book, 1911 (Pretoria: South African Association of Municipal Employees, 1911), 184-185.

Figures for 1904 are from Bell \& Lane, except Krugersdorp and Roodepoort.

Figures for 1910 are from South African Municipal Year Book, 1911, except Pietersburg, which is from the 1913 edition, and Krugersdorp.

Municipality of Krugersdorp, Mayor's Minute, For the Year ending 25 th October, 1904 (Krugersdorp: Standard Printing Works, 1904), 3; Municipality of Krugersdorp, Mayor's Minute for the Year ending 31 October, 1910 (Krugersdorp: Standard Printing Works, 1910), 3. 


\begin{tabular}{|c|c|c|}
\hline Klerksdorp & 3,733 & 4,040 \\
\hline Heidelberg & 3,219 & 2,700 \\
\hline Pietersburg & 3,200 & $4,547(1912)$ \\
\hline Volksrust & 2,382 & 2,300 \\
\hline Barberton & 2,379 & 2,800 \\
\hline Christiana & 2,082 & 1,500 \\
\hline Lydenburg & 1,523 & 1,523 \\
\hline Ermelo & 1,451 & 1,600 \\
\hline Lichtenburg & 1,350 & not given \\
\hline Piet Retief & 1,028 & 900 \\
\hline Vereeniging & 911 & 1,050 \\
\hline Wakkerstroom & 800 (whites) & 1,331 \\
\hline Zeerust & 800 (without natives) & 800 \\
\hline Wolmaransstad & 470 & 1,000 \\
\hline Middelburg & not given & 1,300 \\
\hline Rustenburg & not given & 1,400 \\
\hline Venterstad & not given & 1,100 \\
\hline
\end{tabular}

The size of the permanent local population was a definitive factor. For example, Middelburg did not have a municipal engineer, although it was a major municipality - presumably primarily as a result of its linkage to the Transvaal rail network. On the other hand, some larger urban centres like Barberton, Roodepoort and Springs only appointed town engineers in 1912 and in 1904 both Roodepoort and Springs were already bigger than some major municipalities that did make the appointment. An interesting, possibly related development in Springs was that the population actually decreased from 1904 to 1910. What actually happened in Barberton and Roodepoort was that Barberton had a water bailiff and Roodepoort a foreman of works and in both cases their titles were changed to that of a "town engineer". In the early 1920s the South African District of the British Institution of Municipal Engineers was still considering how to stop unqualified individuals calling themselves "town engineers". Barberton and Roodepoort were not alone in following this practice.

Of the twelve municipalities in the Transvaal only nine had a municipal engineer in 1910. In Standerton, Pietersburg and Heidelberg the municipal engineer's departments were closed during the recession of 1907-1908. ${ }^{9}$ Retrenchment was the order of the day in many municipalities. ${ }^{10}$ For instance, in Pretoria the whole engineering department was reorganised, with some officials dismissed and the salaries reduced of others. ${ }^{11}$

8. W.M.C. Scholtz, 'Die geskiedenis van Roodepoort-Maraisburg tot 1952'. (M.A. thesis, Rand Afrikaans University, 1979), 41.

9 National Archives of South Africa (hereafter NASA), Transvaal Archives (hereafter TAB), TPB, 341, TA1011, Pietersburg Municipality, Minute of His Worship the Mayor for the Year Ending October $1908,16$.

10 This retrenchment policy was the result of a considerable drop in the value of land in 1907. This was partly due to the general feeling of uncertainty of the replacement of the crown colony by responsible government in the Transvaal. The financial crisis of 1907 in Europe and the United States was also an important cause.

Mäki and Haarhoff, 'Municipal engineers in Johannesburg and Pretoria before 1910', 244. 


\section{Engineers}

\section{Training}

From the second half of the 1880s up to 1910, there were 27 municipal engineers in the twelve municipalities in the Transvaal. Three of them, D.C. Leitch, August Karlson and Hugh Daniel Badcock were university-trained engineers, Ernst Lutz had a diploma from Zurich Polytechnic, F.W. Jameson and T.A.J. Forrester had taken university studies and Alfred Pike had studied in Technical School. (See Table 2.) Fourteen of the engineers had been trained through apprenticeship. The educational background of the remaining nine is unclear, but it is highly probable that they also had at least some form of training.

Table 2. Municipal Engineers in the Transvaal 1889-1910

\begin{tabular}{|c|c|c|c|c|}
\hline & Tenure & Nationality & Training & $\begin{array}{l}\text { Reason for } \\
\text { exit }\end{array}$ \\
\hline \multicolumn{5}{|l|}{ Johannesburg } \\
\hline $\begin{array}{l}\text { William Henry } \\
\text { Miles }^{12}\end{array}$ & 1889-1892 & English & Apprenticeship & Dismissed \\
\hline George R. Grey ${ }^{13}$ & $1892-1893$ & $\begin{array}{l}\text { English, born } \\
\text { in India }\end{array}$ & Apprenticeship & $\begin{array}{l}\text { forced to } \\
\text { resign }\end{array}$ \\
\hline Charles Aburrow $^{14}$ & 1893-1901 & English & Apprenticeship & Dismissed \\
\hline $\begin{array}{l}\text { Donald Calder } \\
\text { Leitch }^{15}\end{array}$ & 1902-1904 & English & $\begin{array}{l}\text { Apprenticeship, } \\
\text { studied engineering } \\
\text { at Edinburgh } \\
\text { University }\end{array}$ & other job \\
\hline $\begin{array}{l}\text { G.S. Burt } \\
\text { Andrews }{ }^{16}\end{array}$ & $1905-1927$ & English & Apprenticeship & Retired \\
\hline \multicolumn{5}{|l|}{ Pretoria } \\
\hline Ernst Lutz ${ }^{17}$ & $1896-1897$ & $\begin{array}{c}\text { German from } \\
\text { Hungary }\end{array}$ & $\begin{array}{c}\text { Diploma in } \\
\text { engineering from the } \\
\text { Zurich Polytechnic }\end{array}$ & Resigned \\
\hline August Karlson ${ }^{18}$ & 1899-1902 & Swedish & $\begin{array}{l}\text { Diploma in } \\
\text { engineering from the } \\
\text { University of }\end{array}$ & $\begin{array}{l}\text { Contract } \\
\text { terminated }\end{array}$ \\
\hline
\end{tabular}

14. Institution of Civil Engineers (hereafter ICE), Candidate Circulars, Charles Aburrow, 1 May, 1883 and 18 February, 1898; L. Jackson and W. Martinson, Aburrow \& Treeby. The Architects of Parktown 8. (Johannesburg: Parktown \& Westcliff Heritage Trust, 1989).

Men of the Times: Pioneers of the Transvaal and Glimpses of South Africa. Transvaal Publishing Company, 1905, 155; NASA, TAB, MHG, 66658, Death Notice, George Robert Grey, 2 August, 1928.

ICE, Candidate Circular, Donald Calder Leitch, 23 August, 1898.

ICE, Candidate Circulars, George Samuel Burt Andrews, 23 October, 1894 and 1 December, 1905; NASA, TAB, MHG, 99795, Death Notice, George Samuel Burt Andrews, 23 November, 1937.

17 NASA, TAB, MHG, 62448, Death Notice, Ludvig Ernst Lutz, 19 March, 1927; J. Ploeger, 'E.L. Lutz'. Nerwsletter, Old Pretoria Society, 45, 1980, 2.

Report of the Witwatersrand Water Supply Commission, 1901-1902. (Pretoria: Government Printing and

Institution of Mechanical Engineers (hereafter IME), Membership proposal, William Henry Miles, 6 May, 1889; NASA, TAB, MHG, 0/7865, Sterfkennis, William Henry Miles, 21 March, 1893. Stationery Works, 1902), 123; ICE, Candidate Circular, August Wilhelm Karlson, 20 January, 1905. 


\begin{tabular}{|c|c|c|c|c|}
\hline & & & Stockholm & \\
\hline $\begin{array}{l}\text { Hugh Daniel } \\
\text { Badcock }^{19}\end{array}$ & 1902-1909 & English & $\begin{array}{l}\text { MA in mathematics, } \\
\text { University of Oxford }\end{array}$ & Resigned \\
\hline $\begin{array}{l}\text { F. Walton } \\
\text { Jameson }\end{array}$ & 1909-1920 & South African & $\begin{array}{l}\text { Apprenticeship; } \\
\text { course at the } \\
\text { Technical University } \\
\text { of Nottingham }\end{array}$ & other job \\
\hline \multicolumn{5}{|l|}{ Pietersburg } \\
\hline$?$ & 1903-June 1904 & unknown & unknown & unknown \\
\hline R.W.B. Somerville & July-September 1904 & Australian & unknown & unknown \\
\hline $\begin{array}{c}\text { William Norman } \\
\text { Ashplant }^{21}\end{array}$ & $\begin{array}{c}\text { October-November } \\
1904 \\
\end{array}$ & English & unknown & other job \\
\hline John Anderson & $\begin{array}{c}\text { November-December } \\
1904\end{array}$ & Australian & unknown & dismissed \\
\hline James Younger ${ }^{22}$ & $1905-1907$ & Scottish & unknown & other job \\
\hline John Gillespie ${ }^{23}$ & 1907-1908 & Scottish & Apprenticeship & $\begin{array}{l}\text { forced to } \\
\text { resign }\end{array}$ \\
\hline \multicolumn{5}{|l|}{ Standerton } \\
\hline W.H. Dobson ${ }^{24}$ & $1903-1905$ & English & Apprenticeship & $\begin{array}{l}\text { forced to } \\
\text { resign }\end{array}$ \\
\hline J. Edward Fitt ${ }^{25}$ & 1906-1907 & English & Apprenticeship & dismissed \\
\hline \multicolumn{5}{|l|}{ Boksburg } \\
\hline Harry Good ${ }^{26}$ & 1904-1913 & English & Apprenticeship & resigned \\
\hline \multicolumn{5}{|l|}{ Germiston } \\
\hline T.A.J. Forrester ${ }^{27}$ & 1904-1905 & Scottish & $\begin{array}{c}\text { Apprenticeship; } \\
\text { studies in Edinburgh } \\
\text { University }\end{array}$ & $\begin{array}{l}\text { forced to } \\
\text { resign }\end{array}$ \\
\hline John Riley ${ }^{28}$ & $1906-1907$ & English & Apprenticeship & other job \\
\hline James Bright $^{29}$ & 1908-1932 (acting & Irish & unknown & retired \\
\hline
\end{tabular}

19. ICE, Candidate Circular, Hugh Daniel Badcock, 30 July, 1897; H.St.G. Gray, 'Hugh Daniel Badcock'. Somersetshire Archaeological and Natural History Society: Proceedings, 85, 1939, 243-244. ICE, Candidate Circular, Frank Walton Jameson, 20 November, 1923.

Canadian Great War Project, William

Norman Ashplant, http://www.canadiangreatwarproject.com/searches/soldierDetail.asp?ID=44360. NASA, TAB, MHG, 6348/58, Death Notice, James Younger, 15 August, 1958.

ICE, Candidate Circular, John Gillespie, 28 September, 1886. Simon's Town Museum, Person Register, William Henry Dobson.

ICE, Candidate Circular, John Edward Fitt, 21 January, 1890; NASA, TAB, MHG, 5853/45, Death Notice, John Edward Fitt, 19 October, 1945.

ICE, Candidate Circulars, Harry Good, 1 December, 1898 and 15 April, 1910; 'Mr. Harry Good, A.M.I.C.E., F.R.G.S.'. The East Rand Express, 9 April, 1904; NASA, TAB, MHG, 82025, Death Notice, Harry Good, 11 July, 1933.

IME, Membership proposal, Thomas Adam Jardine Forrester, 22 August, 1905; 'Germiston's Town Engineer'. The East Rand Express, 12 March, 1904.

'The New Town Engineer'. The East Rand Express, 17 March, 1906; South African Who's Who 1909. (Ken Donaldson: Johannesburg and Durban, 1909), 337. 


\begin{tabular}{|c|c|c|c|c|}
\hline & $\begin{array}{c}1905-1906 \text { and } \\
1907-1908)\end{array}$ & & & \\
\hline \multicolumn{5}{|l|}{ Heidelberg } \\
\hline F.A. ter Horst ${ }^{30}$ & 1904-1908 & Dutch & unknown & dismissed \\
\hline \multicolumn{5}{|l|}{ Klerksdorp } \\
\hline Harry Hancock ${ }^{31}$ & 1904-1917 & English & Apprenticeship & retired \\
\hline \multicolumn{5}{|l|}{ Krugersdorp } \\
\hline $\begin{array}{l}\text { Richard A. } \\
\text { Webster }^{32}\end{array}$ & 1904-1914 & English & Apprenticeship & resigned \\
\hline \multicolumn{5}{|l|}{ Potchefstroom } \\
\hline J.A.G. Harrisson ${ }^{33}$ & 1904-1912 & English & unknown & retired \\
\hline \multicolumn{5}{|l|}{ Volksrust } \\
\hline Alfred Pike ${ }^{34}$ & 1904-1921 & English & Technical School & other job \\
\hline \multicolumn{5}{|l|}{ Benoni } \\
\hline $\begin{array}{c}\text { William McGeorge } \\
\text { Mason }\end{array}$ & 1909-1911 & unknown & unknown & unknown \\
\hline
\end{tabular}

\section{The appointment process}

Applications were invited when 22 of the engineers were appointed. Ernst Lutz was a member of Pretoria's temporary town council and possibly the only qualified engineer on the council when he became the first town engineer. ${ }^{35}$ W.H. Dobson and the first town engineer of Pietersburg, whose name could not be ascertained, had been working for the local board of health prior to their appointments as engineers by the new town councils. ${ }^{36}$ James Bright was an assistant town engineer of Germiston, when he was at first named as an acting town engineer and later confirmed as a town engineer. ${ }^{37}$ It is uncertain what transpired at Volksrust.

NASA, TAB, MHG, 6086/44, Death Notice, James Bright, 27 November, 1944; 'Town Engineer Retires'. The East Rand Express, 6 May, 1932.

NASA, TAB, MHG, 4370/52, Sterfkennis, William Antoon ter Horst, 1 August, 1952.

ICE, Candidate Circular, Harry Hancock, 26 September 1893; NASA, TAB, MHG, 47176, Death Notice, Harry Hancock, 6 October, 1921.

IME, Membership proposal, Richard Arthur Webster, 21 March, 1917.

South African Who's Who 1915. (Ken Donaldson: Johannesburg and Durban, 1915), 157.

South African Who's Who 1909. (Ken Donaldson: Johannesburg and Durban, 1909), 372.

The City of Pretoria and Districts. An Official Handbook Describing the Social, Official, Farming, Mining, and General Progress and Possibilities of the Administrative Capital and Surrounding Districts (Johannesburg: Publicity Department, South African Railways, 1913), 70-1; J.J.N. Cloete, 'Die Ontstaan en Ontwikkeling van die Munisipale Bestuur en Administrasie van Pretoria tot 1910', Archives Year Book for South African History, 1960, part 1 (Pretoria: Government Printer, 1960), 133.

NASA, TAB, MST, 1/1/1, Minutes of the Standerton Municipal Council, 5 December, 1903; A.J.J. Du Preez, Standerton 100 (Johannesburg: Caxton, 2000), [no page numbers]; NASA, TAB, MPB, 1/2/1, Minutes of the General Purposes Committee, 13 January, 1904; L. Changuion, Pietersburg: Die eerste eeu, 1886-1986 (Pretoria: Stadsraad Pietersburg, 1986), 89.

NASA, TAB, MGT, 1/1/1/4, Minutes of the Meeting of the Germiston Town Council, 28 February, 1907; NASA, TAB, MGT, 1/1/1/4, Minutes of the Meeting of the Germiston Town Council, 16 August, 1907; 'Germiston Municipality'. The East Rand Express, 13 July, 1907; 'Germiston Town Council'. The East Rand Express, 14 September, 1907. 
In Germiston, Heidelberg, Krugersdorp, Klerksdorp and Boksburg the first town engineers were appointed between the last week of January and first week of March 1904, shortly after the formal establishment of municipalities. ${ }^{38}$ In Volksrust, Alfred Pike was appointed as a town engineer already under the urban district board in January $1904 .{ }^{39}$ In Potchefstroom, preparation for a town engineer started immediately after the creation of the municipality. However, the appointment was only made in October $1904 .{ }^{40}$ Benoni's first town engineer was the only one to be appointed more than one year after the creation of the municipality. ${ }^{41}$

The outstanding exception of all the municipalities was Johannesburg, where the first town engineer was appointed in 1889, eight years before the formal establishment of the municipality. ${ }^{42}$ In 10 of the 12 appointments (83\%) of the first town engineers there is a link to the establishment of the local government.

\section{Earlier work experience}

In all known cases, previous experience played a significant role in the selection process. Most of the engineers already had working experience from the United Kingdom and other parts of South Africa; ten of them had been working in the other parts of the world. ${ }^{43}$ In all cases where background is known (25 out of 27) the engineer was at the time of appointment either already working in South Africa or, as in the cases of W.H. Miles and D.C. Leitch, had previous experience from South Africa. ${ }^{44}$ Only T.A.J. Forrester and F. Walton Jameson had earlier experience of a similar position in some other municipality. ${ }^{45}$

\section{Termination of the tenure}

If we look at the termination of the tenures of the town engineers, it seems that their task was far from easy. Three of the engineers, W.H. Miles, Aburrow and John Anderson were dismissed. Four, George R. Grey, Ernst Lutz, W.H. Dobson and T.A.J. Forrester, resigned because of alleged

NASA, TAB, MGT, 1/1/1/1, Minutes of the Meeting of the Germiston Town Council, 28 January, 1903; 'Germiston Town Council'. The East Rand Express, 30 January, 1903; NASA, TAB, MKR, 1/1/1/1, Minutes of the Krugersdorp Town Council, 9 February, 1904; NASA, TAB, MKD, 1/1/1/2, Minutes of the special Meeting of Klerksdorp Town Council, 23 February, 1904; NASA, TAB, MBO, 1/1/1/1, Minutes of the Boksburg Municipal Council, 2 March, 1904; 'Boksburg Town Council'. The East Rand Express, 5 March, 1904.

D.N. Miller, Short History of Volksrust (Johannesburg: Hortors, 1933), 9.

NASA, TAB, MPO, 1/1/1/3, Minutes of the Potchefstroom Town Council, 23 June, 1904; NASA, TAB, MPO, 1/1/1/3, Minutes of the Potchefstroom Town Council, 18 August, 1904.

NASA, TAB, MB, 1/1/3, Minutes of the Benoni Town Council, 18 November, 1909; 'Benoni Town Council'. The East Rand Express, 20 November, 1909.

Mäki and Haarhoff, 'Municipal engineers in Johannesburg and Pretoria before 1910', 231-232.

Before coming to South Africa Grey had been working in the USA and some South American countries, Lutz in Switzerland, Karlson in France and on both the Suez and Panama Canals, Somerville and Anderson presumably in Australia, Fitt in Argentina, Ter Horst in Netherlands, Hancock in Philippines, Webster in India and Pike in Russia, France and Italy.

Miles had been working in Port Elizabeth before returning to England and Leitch had been the civil engineer in responsible charge of the Admiralty works at the Cape of Good Hope in early 1890s.

Forrester was assistant town engineer of East London and had been acting town engineer there before coming to Germiston. Jameson was borough engineer of Pietermaritzburg before his appointment to Pretoria. 
misconduct. Two municipal engineers, John Gillespie and Harry Good, resigned as a result of differences with the local politicians. ${ }^{46}$ With the benefit of hindsight, at least in the case of Aburrow, there was no misconduct. ${ }^{47}$ Of the other six, Grey's and Dobson's actions appear to come under the definition of corruption. ${ }^{48}$ Such allegations, in the case of Miles, Lutz and Forrester, are rather less clear. Lutz was exonerated of any misconduct and Miles had defenders who claimed that the sanitary board had been too eager to see misconduct were there was none. ${ }^{49}$ Forrester was apparently a victim of Germiston's Work Committee's frugality. ${ }^{50}$ Anderson was dismissed for drunkenness. ${ }^{51}$ R.A. Webster probably resigned due to new office arrangements. J. Edward Fitt and F.A. ter Horst were dismissed because of the retrenchment policy and the resignation of H.D. Badcock was also directly connected to this. ${ }^{52}$ August Karlson was not allowed to remain in his position. ${ }^{53}$ Six of the engineers, D.C. Leitch, F. Walton Jameson, W.N. Ashplant, James Younger, John Riley and Alfred Pike, resigned and moved on to greener pastures. ${ }^{54}$ Only G.S. Burt Andrews, James Bright, Harry Hancock and J.A.G. Harrisson went voluntarily into retirement. For three of the engineers, the unknown first engineer of Pietersburg, R.W.B. Somerville and W.M. Mason, we have no clear reasons for their departure.

\section{Conclusion}

Looking at the development in these twelve municipalities and thinking about the two groups mentioned in the introduction, we can see that there are really no differences in timing for the appointment of the first town engineer. Nearly all these municipalities appointed the first engineer within a few months of their establishment. The position of engineer in relation to the municipal

NASA, TAB, MPB, 1/2/4, Minutes of the General Purposes Committee, 18 February, 1908; NASA, TAB, MPB, 1/2/1, Minutes of the General Purposes Committee, 17 March, 1908; 'Boksburg Town Council'. The East Rand Express, 15 February, 1913; 'Municipal Re-Organization'. The East Rand Express, 22 February, 1913; 'The Boksburg Municipal Muddle'. The East Rand Express, 12 April, 1913; A.W. Heinemann, 'The Boksburg Municipal Muddle'. The East Rand Express, 19 April, 1913; 'Boksburg Municipal Staff. The East Rand Express, 3 May, 1913.

Mäki and Haarhoff, 'Municipal engineers in Johannesburg and Pretoria before 1910', 238-240.

Mäki and Haarhoff, 'Municipal engineers in Johannesburg and Pretoria before 1910', 234; NASA, TAB, MST, 1/1/2, Minutes of the Special meeting of the Standerton Municipal Council, 26 November, 1905. Dobson was later town engineer in Grahamstown 1912-1919, in Vereeniging 1919-1921 and in Krugersdorp from 1921. The incident at Standerton apparently did not have any damaging repercussions for his career.

Mäki and Haarhoff, 'Municipal engineers in Johannesburg and Pretoria before 1910', 233, 236-237.

NASA, TAB, MGT, 1/1/1/2, Minutes of the Meeting of the Germiston Town Council, 14 December, 1905; Ratepayer, 'Municipal Officials'. The East Rand Express, 30 December, 1905; 'The Recent Disturbance'. The East Rand Express, 13 January, 1905; L. de Kock, 'Geskiedenis van Germiston 1886-1986'. Unpublished manuscript in Germiston Public Library, Africana Collection, 89; 'The New Town Engineer'. The East Rand Express, 17 March, 1906.

NASA, TAB, MPB, 1/2/1, Minutes of the General Purposes Committee, 13 December, 1904.

NASA, TAB, MST, 1/1/3, Town Council meeting, 26 July, 1908; NASA, TAB, MHB, 1/1/1/3, Town council meeting, 25 November, 1907; NASA, TAB, MPA, 1/1/1/15, Town Council meeting, 27 August, 1908.

53 Mäki and Haarhoff, 'Municipal engineers in Johannesburg and Pretoria before 1910', 240-241.

Leitch became a chief engineer of Rand Water Board, Jameson went to Kimberley as a town engineer, Ashplant went to Nigeria, Younger became an engineer to the General Council of Tanskei in Umtata, Riley was appointed as sewerage engineer of Johannesburg, and Pike went to Rhodesia to be a town engineer in Umtali. 
council was also very similar; for instance, dismissals occurred in both groups. However, a difference is apparent in the financial situations of the municipalities. All those instances where there were considerable cuts in engineering departments or even closures of whole departments during the depression of the late 1900s happened in municipalities outside the mining area.

Relations between town engineers and municipal politicians seem to be very similar in all twelve municipalities. The town councils and council committees carefully scrutinised engineering departments' activities. They also kept an eye on town engineers. If there were differences of opinion, the town engineers were always on the losing side.

The available evidence suggests that there were many uncertainties in the job description and powers of the municipal engineer. For instance, it seems that it was unclear to many municipal decisionmakers what personal qualities were necessary for a successful municipal engineer. This state of affairs created serious problems. A town council could still dismiss a town engineer or force his resignation at very short notice. Town councillors clearly took their supervisory duties seriously. Expenditure, often a major category on the balance sheet of engineering departments, tended to be substantial under circumstances of local urban development. Consequently, the cheapest tenders would generally be accepted in an effort to prevent the 'waste' of money. All allegations of misconduct and corruption were taken seriously - perhaps far more so than is the case today. Furthermore, it appears as if the engineers themselves were unsure of what was expected of them, or what kind of working environments awaited them in South African towns. And even if the engineers had experience from the towns in the Cape Colony, the working environment in the Transvaal, especially in mining towns, was quite different.

Most historians are not comfortable with giving lessons from the past, and I am one such. Be that as it may, in light of this research it is clear that the tasks of the municipal official like the town engineer have to be clearly defined. The working experience, qualifications and the ability of the person appointed should also have an impact on this. If there are any grey areas in the responsibilities of the position difficulties will inevitably ensue. 